\title{
Benign Pericardial Germ Cell Tumor
}

National Cancer Institute

\section{Source}

National Cancer Institute. Benign Pericardial Germ Cell Tumor. NCI Thesaurus. Code C147106.

A non-metastasizing germ cell tumor that arises within the pericardium. 